\title{
A COMPETENCY FRAMEWORK FOR VIRTUAL HR PROFESSIONALS IN AN ARTIFICIAL INTELLIGENCE AGE
}

\author{
Dr. Bharti Pandya* \\ Dubai Women's College, Higher Colleges of Technology, United Arab Emirates
}

\begin{abstract}
.
$\mathrm{HR}$ is at the crossroads where digitization has transformed workplace to the virtual workplace. The Artificial Intelligence (AI) is risking jobs creating shortage of competencies like creativity, imagination, innovation, adaptability, and cognitive skills. The purpose of this research is to systematically investigate the competencies required in virtual HR professionals in the AI Age, to critically analyse the HR competencies, and to develop a HR Competency model aligned with the HR jobs expected in 2030.

An Interpretivism- Deductive approach was applied to analyse HR competencies, using PRISMA model. The interviews of 16 HR professionals were thematically analysed to synthesis the Competencies required in the virtual HR professionals in an AI age. An InductiveLatent analysis approach and six phases of thematic analysis were administered to extract competency domains, competency clusters, and competency factors.

The thematic analysis produced 36 competencies, 14 clusters, and allocated to 4 competency domains. The 14 competency clusters included competencies such as Data science, Agreement/Contract management, managing time zones, mobile HR, instant HR, social branding and technological business acumen.

A Virtual HR Competency model was developed to scholars and practitioners with interest in future HR jobs, competencies development, virtual professionals, HR automation, and Artificial intelligence in HR.
\end{abstract}

Keywords: Artificial intelligence in HR; Competency Models; HR Competencies; Virtual HR; Virtual professionals

\section{Introduction}

Human Resources (HR) is at the crossroads where the fast-paced technological changes have transformed physical workplace to the virtual workplace. The Artificial Intelligence (AI), Robotics, Virtual Reality, and Augment reality have paved its path into the HR functions 
like Recruitment, Learning, Employee communication, Data Analytics, Workforce Directory, Compensation \& Benefits management, Employee services and other administrative functions. The Towers Watson Survey conducted across 32 countries found that $60 \%$ of respondents provide mobile access to their employees for HR related services (Lejeune, 2013). Mobile HR is the new norm and organizations are adopting HR applications like HR Intouch Mobile; HRO Mobile; FutuHR; Youforce; and Zenefits Mobile App to provide instant services to employees.

While the globalization and internationalization, with the support of $4 \mathrm{G}$ data connections, has surged the number of telecommuters; the Artificial Intelligence has automated the HR functions. The HR Service centres, Outsourcing, Self-service, Digital Assistants and ChatBots have redefined the work, workforce, and the workplace (Manuti \& de Palma, 2017).

The PwC report titled 'Workforce from the Future' suggests that competencies like emotional intelligence, creativity, persuasion, innovation will become valuable as by 2030, "the future of humans at work is questioned" (PwC, 2018, P.27). The report further elaborates that the automation has already risked $38 \%$ of the jobs in the US and that 52\% CEOs have been experiencing a shortage of competencies like creativity, imagination, innovation, adaptability, and cognitive skills. Another study by McKinzie predicted that by 2030,75 million to 375 million workforce will need to change their occupations as existing jobs will be replaced by automation (Manyika et al., 2017). The same report suggested that in UAE, 35-40\% of "current work activities will be displaced by automation by 2030 , while more than $50 \%$ current work activities in Canada, Austria, Germany and Italy will be displaced by automation."

The above developments such as globalization, virtual organizations, HR automation, and Artificial Intelligence will require a new set of competencies. Since HR has already shifted to the virtual and mobile arena, the futuristic HR competencies need to be identified and defined so that the Generation Z (born between 1995 -2010) can be prepared for the future HR jobs. The purpose of this research paper is to systematically investigate the competencies required in virtual HR professionals in the Artificial Intelligence Age. This research aims to critically analyse the existing HR competencies and models and thereafter develop a conceptual HR Competency model aligned with the HR jobs expected in 2030 .

\section{Research Framework}

\subsection{Research Paradigm and Methodology}

My ontological belief is that there is a continuous evolution of the workplace and technological advancements have been shaping the jobs, organizations, and individuals operating within and outside these organizations. Fundament on this, my epistemological assumption is that the complex nature of organizations, jobs, and individuals is anchored in an individual's perspective. In order to study any unknown phenomena like futuristic jobs or competencies required in the nascent age of Artificial Intelligence, one will shift to the Constructivist 
Research paradigm (Creswell, 2009; Patel, 2015). An Interpretivism- Deductive approach is applied in this study wherein the HR competencies and models were systematically analysed using the PRISMA model (Hébert, Durand, Dubuc, \& Tourigny, 2003). The semistructured interviews of $16 \mathrm{HR}$ professionals were thematically analysed to synthesis the Competencies required in the virtual HR professionals in an Artificial Intelligence age (hereafter, AI). An Inductive-Latent thematic analysis approach and Six phases of thematic analysis were administered to interpret, analyse, and report the data (Braun \& Clarke, 2006) and to extract competency domains, competency clusters, and competency factors.

\subsection{Research Objectives and Questions}

The primary objective of this empirical study is to systematically analyze the existing HR competencies, the theoretical competency frameworks and compare them with the competencies required in the virtual HR professionals in the age of AI. The research focused on three questions:

1. What are the HR Competencies, HR Competency models, and competencies for the virtual HR professionals?

2. How Artificial Intelligence age will affect the existing virtual HR competencies?

3. What virtual HR competencies will be required by the year 2030 ?

\subsection{Research Methods}

This is an empirical qualitative study where sequential mixed methods were applied in two stages. Both primary data and secondary data were thematically analysed to understand the HR competencies required in future HR professionals. In the first stage, secondary data was collected through database searching using the keyword criteria. The keywords searched included Competency, Competency Models, HR Competencies, HR Competency Models, Artificial Intelligence in HR, Future jobs in HR, and HR Automation. The database used for this research included Proquest, Ebsco, Elsevier, Emerald, Google Scholar and ScienceDirect. Meta-analysis of existing literature was conducted using the Preferred Reporting Items for Systematic Reviews and Meta-Analyses (PRISMA) model (Hébert et al., 2003). The identification, screening, eligibility, and inclusion of the literature set is depicted in Figure 1. The gaps were identified from the existing literature in the context of the research objective and questions.

The gaps identified from the Meta-analysis became the basis to develop the questionnaire for semi-structured interviews. The review of the questionnaire by two experienced researchers established the content validity. An open request was sent to the HR professionals through professional networks including LinkedIn, SHRM community, CIPD community and CiteHR. 33 professionals self-selected themselves for an online interview. 12 respondents were excluded due to not meeting the criteria of performing HR function on a virtual platform and 5 respondents declined the request to audio record the interview. The respondents were sent the Participant Consent Form detailing the purpose 
of the study, voluntary participation and withdrawal clause, confidentiality statement, and data management process. Only 16 respondents gave the consent and participated in this study. The profile of the respondents is summarized in Table 1. It is evident from the profile that all participants are HR professionals performing more than $70 \%$ of their job using online platform whether it be the organizational portal, mobile network, or telecommute.

Latent and Inductive Thematic analysis was conducted to identify, analyse and report the virtual HR competencies themes derived from the semi-structured interviews. This method was an appropriate choice as the study was not engaged to any pre-existing competency or theoretical framework (Braun \& Clarke, 2006). In order to ensure the reliability of the interview coding, interpretive synthesis was conducted wherein the 24 pages of the transcript was coded. To minimize the error of personal bias, two researchers were deployed for independent coding. The comparison across the codes derived from both researchers resulted in 143 unique quotations. Out of 143 quotations, 23 quotations were not relevant to the HR Competencies and virtual HR professionals and 8 codes were too descriptive to be associated with any competency related theme. Total of 112 quotations were directly related to the HR competencies required in HR professionals to perform effectively on an online/virtual platform. Furthermore, 116 quotations coded by both the researchers resulted in high inter-coder reliability of $81.8 \%$ suggesting an acceptable level (Stevens, Lyles, \& Berke, 2014).

Figure 1: PRISMA flow chart for the systematic review of the literature 


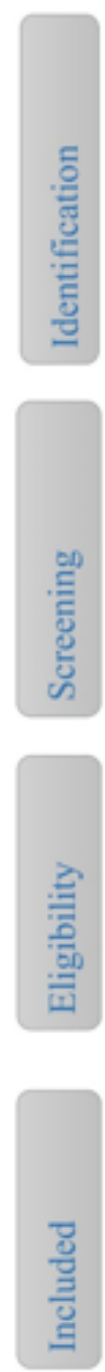

2652Records identified through database searching "Proquest, Ebsco, Elsevier, Emerald, Google Scholar and Science Direct"

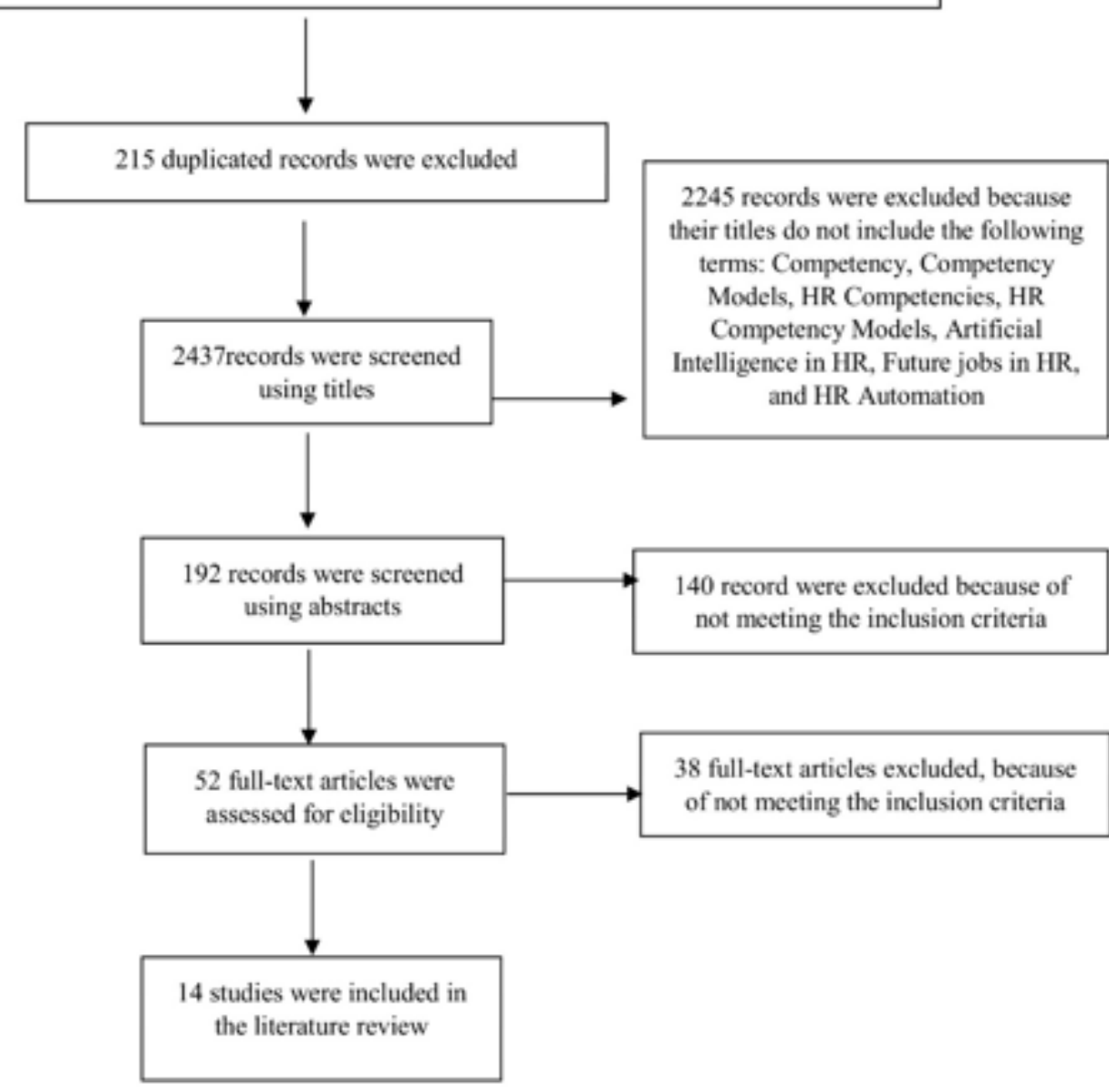


Table 1: Profile of the Respondents

\begin{tabular}{|c|c|c|c|c|c|c|c|c|}
\hline $\begin{array}{l}\text { Respondent } \\
\text { (R\#) }\end{array}$ & Job Title & HR Domain & $\begin{array}{l}\text { Work } \\
\text { Location }\end{array}$ & $\begin{array}{l}\text { Years of } \\
\text { experience } \\
\text { in this } \\
\text { function }\end{array}$ & $\begin{array}{l}\text { Job } \\
\text { performed } \\
\text { online (in \%) }\end{array}$ & Sector & $\begin{array}{l}\text { Organizational } \\
\text { Coverage }\end{array}$ & $\begin{array}{l}\text { Nos. of } \\
\text { employees }\end{array}$ \\
\hline $\mathbf{R 1}$ & Remote HR Generalist & Service & US & 2 & 100 & Insurance & International & 24,500 \\
\hline $\mathbf{R 2}$ & Mobile HR Business Partner & Service & Sweden & 6 & 95 & Retail & International & 39,000 \\
\hline $\mathbf{R 3}$ & Remote Senior HR Consultant & Advisory & Sweden & 15 & 95 & Consultation & National & 623 \\
\hline $\mathbf{R 4}$ & $\begin{array}{l}\text { Virtual Talent Acquisition } \\
\text { Manager }\end{array}$ & Staffing & Austria & 8 & 100 & Manufacturing & National & 2300 \\
\hline R5 & Online HR Advisor & Advisory & UAE & 11 & 80 & Media & International & 450 \\
\hline R6 & Online HR Consultant & Advisory & US & 14 & $80-90$ & Education & International & 1,700 \\
\hline $\mathbf{R 7}$ & HRIS Strategic Manager & Strategic & Japan & 12 & 75 & Manufacturing & International & 12,000 \\
\hline $\mathbf{R 8}$ & Remote HR Project Manager & Strategic & Germany & 19 & $85-90$ & Health Care & International & 8,700 \\
\hline R9 & HR Payroll Technical Consultant & Compensation & India & 16 & 100 & Banking & National & 42,800 \\
\hline R10 & $\begin{array}{l}\text { Online People Development } \\
\text { Officer }\end{array}$ & $\begin{array}{l}\text { Learning and } \\
\text { Development }\end{array}$ & New Zealand & 6 & $80-90$ & Consultancy & National & 250 \\
\hline R11 & $\begin{array}{l}\text { Telecommute Recruiting } \\
\text { Marketing Analyst }\end{array}$ & Staffing & India & 4 & 100 & $\begin{array}{l}\text { Information } \\
\text { Technology }\end{array}$ & International & 27,000 \\
\hline R12 & $\begin{array}{l}\text { Artificial Intelligence in HR } \\
\text { Program Director }\end{array}$ & Strategic & India & 2 & 70 & $\begin{array}{l}\text { Information } \\
\text { Technology }\end{array}$ & National & 14,800 \\
\hline R13 & Onboarding Success Partner & Operational & US & 3 & 100 & Education & International & 927 \\
\hline R14 & Chief HR Technology Officer & Strategic & India & 6 & 80 & Retail & International & 35,000 \\
\hline
\end{tabular}




\begin{tabular}{|c|c|c|c|c|c|c|c|c|}
\hline R15 & A. I. Recruiter & Staffing & Canada & 2 & 100 & Insurance & International & 1,100 \\
\hline R16 & Employee Experience Architect & Service & India & 4 & $75-80$ & Consultancy & National & 142 \\
\hline
\end{tabular}




\section{International Conference on Applied Research in

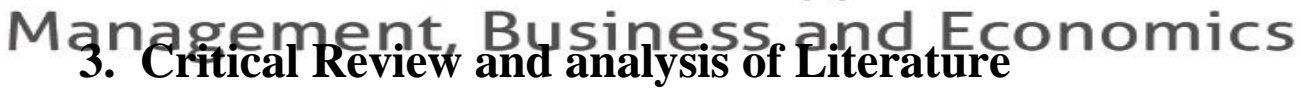

Developing competencies has remained an HR role from the era of Scientific Management where rewards were paid for performance (Bondarouk, Marsman, \& Rekers, 2014). HR remained a driving factor for attaining sustainable business success through operational, relational, and transformational role (Kakabadse \& Kakabadse, 2000; Lawler, Fitz-enz, Madden, Ulrich, \& Books24x7, 2004; Swanson \& Holton, 2009; Venegas \& Thill, 2015). Studies suggest that the role of HR is evolving in nature (Byrd, 2017; Gosney \& Hughes, 2016; SHRM, 2008) and that the competencies of HR professionals amend simultaneously (Yeung, 1996). This section will critically review the term competency and systematically analyze the existing HR competency models.

\subsection{Competency}

The term 'competency' is widely studied by practitioners as well as scholars. The concept of competency was first introduced by McClelland (1973) who propound that the individuals are to be tested for their competence and not intelligence. Since then different scholars defined competency with different perspectives (Bowden and Master, 1993). Ilham (2012) analysed various definitions of the competencies and acknowledged three positions used by scholars, namely, the observable performance, outcome of the performance, and the attributes of a person. The work of Boyatzis $(2008,2011)$ is worth reviewing as he aligned all three positions through studying the competencies in the management field. He defined competency as "an underlying characteristic of a person which results in effective and/or superior performance in a job" and posited that the competency includes "a motive, trait, skill, aspect of one's self-image or social role, or a body of knowledge which he/she uses." (Boyatzis, 1982, cited in Ilham, 2012). Emerging from the definitions with displayed behaviour to perform successfully, Boyatzis (2008) posited that emotional and social competencies cannot be ignored. Built on the Boyatzis's work, Swanson and Holton (2009) defined competency as "displayed behaviour within a specialized domain in the form of consistently demonstrated actions of an individual which are both minimally efficient in their execution and effective in their results" (P.268). While discussing 'competency', the definition given by Spector (1997) is to be considered as it is widely used by the HR practitioners while developing competencies for their workforce. Spector presented the competency as a combination of knowledge, skills, abilities, and other characteristics present in an individual.

The review of the definition of the word 'competency' reflects the ambiguity of the word with the wide application based on the applicant. Since there is no concrete definition of competency, it becomes indispensable to identify the HR Competencies presented in various HR Competency Models.

\subsection{HR Competencies and Models}

The studies suggest that the HRM competencies have evolved from the era of Scientific Management to the Digital Age (Marsman, Bondarouk, \& Rekers, 2014). The progressive work in identifying and describing HRM competencies indicates that the existing competencies will change in the age of Artificial Intelligence. The work of Rekers (2013) is to be appreciated as he time-lined the HRM competencies from the year 1880 to 2010 (Marsman et al., 2014). As mentioned earlier, the competencies are correlated with the performance, earlier the HRM competency was to motivate people through rewards. Figure 2 depicts the evolution of HRM 


\section{International Conference on Applied Research in}

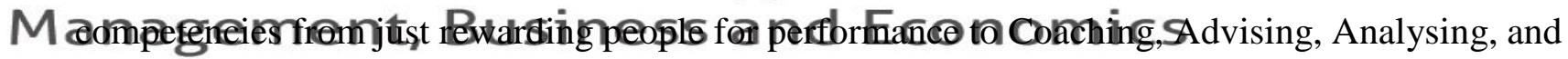
Becoming Strategic.

Figure 2: Evolution of HR Competencies

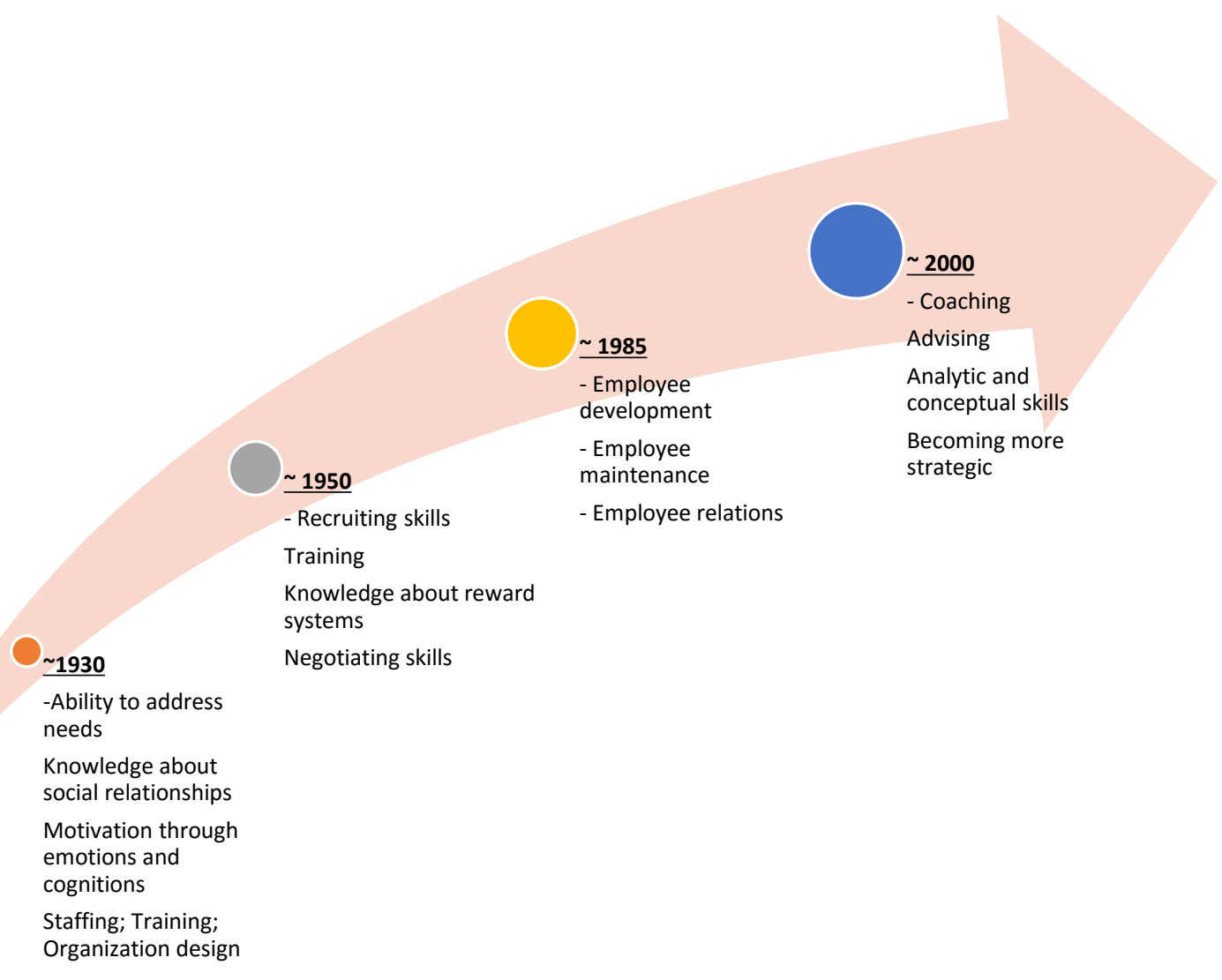

(Adapted from Rekers, 2013)

As the meaning of the word 'competency' was observed from different perspectives, the identification and clustering of the competencies also resulted in very broad and ambiguous competency models. The scholars who viewed the competency as a performance outcome developed a competency model as "a list of competencies which are derived from observing satisfactory or exceptional employee performance for a specific occupation. It provides identification of the competencies employees need to develop in order to improve performance in a current job or to prepare for other jobs" (Draganidis \& Mentzas, 2006). The researchers such as Cooper (2000), with a perspective of competency as a performance standard, defined competency model as "collection of competencies and standards of performance establishing qualifications for a specific job position". While the researchers who concur with the concept of KSAOs, defined a competency model as "a descriptive tool that identifies the skills, knowledge, and personal characteristics as well as behaviours needed to perform a role effectively in an organization, and to help the business meet its strategic objectives." (Mucia \& Lepsinger, 1999, cited in Venegas \& Thill, 2015). 


\section{International Conference on Applied Research in}

Ma r Taeģ from the year 1988 - 2016. During this period, 7 rounds of studies were made, the summary of the HRM competencies are presented in Appendix 1. In the first four rounds, Business knowledge, HR Delivery, and Change remained the constant competencies denominator with the addition of Personal credibility in 1992; Culture in 1997; Strategic Contribution and HR Technology in 2002 and a complete revamp in the HR competencies in 2007. The technology took over the performance and competency aspects in a short span of five years (2002-2007) and in 2016 study, the competencies like Technology \& Media Integrator and Analytics Designer\& Interpreter were added. These developments in HRM Competency suggests that Technology and now, Online social networking, Automation, Robotics, and Artificial Intelligence are the driving forces for the drastic changes in the HR Competencies. However, the HR Competency studies (HRCS) conducted by Ulrich and team focused only on the HR competencies related to individual and organizational performance. The behavioural, social and emotional competencies took a backseat (Boyatzis, 2011).

Apart from Ulrich's Model of HR Competency, six (6) more HR Competency Models were analysed, the summary of which is presented in Appendix 2. A total of 45 competencies were extracted by combining the $6 \mathrm{HR}$ competency models developed by the American Society for Training \& Development (ASTD,1988); Kearns (2001); Selmer and Chiu (2004); Chen (2005); Society of Human Resources Management (SHRM,2012), Chartered Institute of Personnel Management (CIPD, 2013), and Ulrich (2016).

The rapid comparison analysis of these models reveals the similarity as well as variations in HR competencies. The competencies like Business Acumen (or knowledge) and Leadership are evident in all the models, except in Ulrich's model which presumably have been included in the Strategic competency. Other common HR competencies apparent in these models include HR knowledge, interpersonal relationship, strategy architect and positioning, teamwork, and technological acumen. The competencies that are singled out include analytical thinking, compliance management, Consultation and advisory skills, courage to challenge, critical evaluation, curious, employee engagement, ethical practice, human capital curator, influencer, integrity, international management, media integrator, negotiator, professionalism, role model, system thinking, and trust.

The Cluster analysis indicates that ethics \& compliance have been marginalized to affect the HR professionals' capabilities to influence others and establish interpersonal relationships on trust and integrity. These competencies are crucial in virtual HR professionals, especially for those who deal with vendors and employees. Clearly, these studies did not take into account the automation of the functions and the outsourcing of the HR functions and hence failed to address the competencies required in HR professionals to function in the age of Artificial Intelligence.

The studies conducted till date are limited in addressing the future of HR professionals in light of the age of Artificial Intelligence dominated by the digital workforce, digital workplace, and new jobs.

\subsection{Virtual HR}

The virtual HR is a synonym to e-HR, online HR, Web HR, and Digital HR (Bondarouk, Parry, \& Furtmueller, 2017). Virtual HR is relatively a new phenomenon in HR discipline and the studies 


\section{International Conference on Applied Research in}

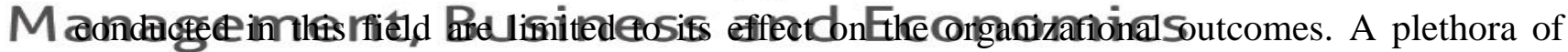
researchers defined virtual HR (Gardner, Lepak, \& Bartol, 2003; Lepak \& Snell, 1998; Melcer, 2001; Ruël, Bondarouk, \& Van der Velde, 2007) that suggests that the technological advancement enables the HR departments to create value for the organization and employees. Lepak and Snell (1998) attributed the wide acceptance of virtual HR on account of enhanced service, cost reduction, and strategic orientation. Ruël et al. (2007) proposed a model of e-HRM and classified e-HRM in three categories: operational e-HRM; relational e-HRM; and transformational e-HRM.

The HR functions have been transformed from face-to-face delivery to virtual platforms. The HR departments have been converted into virtual HR departments. Snell, Stueber, and Lepak (2001) defined virtual HR department as a "network-based structure built on partnerships and mediated by information technologies to help the organization acquire, develop, and deploy intellectual capital" (P.6). Gardner et al. (2003) observed that the technology has automated and informed the operational HR; the remote access has facilitated relational HR, and the redefined workplace and systems has elevated the strategic and transformational HR. Baker (1992) highlighted the growing reliance of virtual HR on technology and complete automation of HR functions like benefits administration, recruitment, employee record keeping, and HRIS.

The advancement in virtual HR is likely to have implications on the competencies of HR professionals (Sparrow \& Daniels, 1999, cited in Gardner et al., 2003), rechristened as virtual HR professionals.

\subsection{Virtual HR Competencies in AI Age}

The Harvey Nash HR Survey found that $28 \%$ of organizations have grasped the impact of AI on the workforce planning while $46 \%$ expect AI to invade in next 2-5 years. It is found that by 2030, AI and automation will impact the workforce planning by 85\% (Harvey Nash, 2018). The research conducted by $\mathrm{PwC}$ reveals that " 40 percent of the HR functions of international companies are currently using AI-applications" with Assisted Intelligence. Augmented Intelligence is emerging in HR discipline and Autonomous Intelligence is expected to $100 \%$ automate the HR departments by 2030. In light of these findings, the competencies of virtual HR professionals needs to be revisited.

The virtual HR is characterized by its increased flexibility, accessibility, speed, userfriendliness, and swift support to employees and organizations to attain goals. The adaptability, problem-solving skills, collaboration skills, emotional intelligence, creativity \& innovation, leadership skills, and digital skills will be at the top of the virtual competency pyramid (Charlier \& Kloppenburg, 2017).

The virtual HR professionals are obligated to possess competencies to positively enhance HR efficiency, HR effectiveness, HR cost savings, HR service-improvements, relationship management, attitude management, HR communications, globalization, change management, and knowledge management (Gardner et al., 2003). With the increased outsourcing of HR functions, Lawler et al. (2004) suggested virtual HR professionals have a competency to manage external partnerships.

Limited scholarly studies have been conducted in the field of competencies for virtual HR professionals. However, the researchers conducted by the HR practitioners and leaders provides an insight into the current competencies and competencies of the future. Wilson Wong, the Head 


\section{International Conference on Applied Research in}

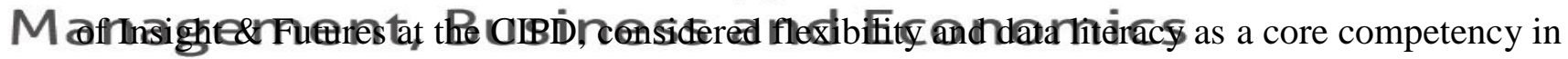
the AI age, complemented by adaptability, lifelong learning and skills development, and data understanding (HQ Asia, 2017). Nunn (2018) proposed virtual HR professionals to be competent to manage virtual teams comprised of machines and telecommuters. The other virtual competencies discussed by practitioners include Digital IQ (EY, 2018); trust (Svetlik \& StavrouCostea, 2007); critical thinking and creativity (Shook \& Knickrehm, 2017); redesigning jobs and data storytelling (Min, 2017).

It is evident from the above review and analysis that limited research is conducted to develop a competency model for virtual HR professionals. Based on the gaps identified in the literature and the secondary data, the second stage of the research was conducted wherein semi-structured interviews of 16 virtual HR professionals was conducted.

\section{Data Analysis and Findings}

Inductive thematic analysis was conducted as the data was coded irrespective of the researcher's analytic preconceptions. The review of the literature on virtual HR competencies provided a minimal base for developing the theoretical framework to structure the questions (Maguire \& Delahunt, 2017). The semi-structured interview of 16 diversified international HR professionals provided leverage to collect rich data with respect to competencies practised, experienced, and envisioned for future. Latent themes were developed to develop a conceptual model.

The thematic analysis was conducted using six phases prescribed by Braun and Clarke (2006). The researcher familiarized herself with the data; generated initial codes with assistance from two other researchers; collated codes to search for themes; reviewed themes through concept map; defined and named the themes; and reported the themes in Table 2. The re-reading of the transcribed data and listening to the audio data resulted in the data immersion and coding phase.

The virtual HR competencies that sprouted during the meta-analysis became the foundation for the interview and analysis. Though not completely relied on the competencies, the researcher focused on an inductive approach considering the non-validity of the competencies emerged from literature. Using the work of Bondarouk et al. (2017), three arms of e-HRM were used and competencies were conceptually mapped. The frequency analysis (Appendix 3) was done to verify if the virtual HR professionals consider these competencies relevant to their job. 


\begin{tabular}{|c|c|c|c|c|}
\hline $\begin{array}{l}\text { Competency } \\
\text { Domain } \\
\text { (Thematic area) }\end{array}$ & $\begin{array}{l}\text { Competency } \\
\text { Cluster } \\
\text { (Second- } \\
\text { order theme) }\end{array}$ & $\begin{array}{l}\text { Competency Factor } \\
\text { (First-order theme) }\end{array}$ & Verbatim Data extract & $\begin{array}{l}\text { Interview } \\
\text { Respondent } \\
\text { Identifier }\end{array}$ \\
\hline \multirow[t]{11}{*}{$\begin{array}{l}\text { Operational } \\
\text { virtual HR }\end{array}$} & \multirow[t]{2}{*}{ Data Science } & Data interpretation & $\begin{array}{l}\text { "The management is keen on bottom-line. They want to hear numbers, not stories. We } \\
\text { have systems in place to generate reports, but interpreting the data is my job. I need to } \\
\text { make sense of the data." }\end{array}$ & R11 \\
\hline & & Data analysis & $\begin{array}{l}\text { "There was a time when I was feeding data into the software to process salaries. The } \\
\text { systems have changed, too much. Now, I analyze the reports" }\end{array}$ & R9 \\
\hline & \multirow[t]{3}{*}{$\begin{array}{l}\text { Agreement } \\
\text { Management }\end{array}$} & Drafting agreements & $\begin{array}{l}\text { "I wish machines learn quickly to draft customized clients' requirements. I need to pull } \\
\text { information from the application forms and edit the drafted agreement. Thank god } \\
\text { machines do not have brains to think, and I have." }\end{array}$ & R3 \\
\hline & & Intellectual property & "The codes we develop are protected by the intellectual property laws." & $\mathrm{R} 12$ \\
\hline & & $\begin{array}{l}\text { Confidentiality } \\
\text { agreements }\end{array}$ & $\begin{array}{l}\text { "Ethical compliance department does not tolerate any breach of confidentiality } \\
\text { agreements" }\end{array}$ & $\mathrm{R} 12$ \\
\hline & $\begin{array}{l}\text { Managing } \\
\text { time-zones }\end{array}$ & $\begin{array}{l}\text { Time-zones } \\
\text { management }\end{array}$ & $\begin{array}{l}\text { "In management program, we got the training in time-management but nobody taught } \\
\text { managing different time-zones. It comes with experience." }\end{array}$ & $\mathrm{R} 1$ \\
\hline & \multirow[t]{2}{*}{ Mobile HR } & $\begin{array}{l}\text { Knowledge of HR } \\
\text { Mobile application }\end{array}$ & $\begin{array}{l}\text { "I should know which tab they should click to get their answers related to leave request, } \\
\text { directory, or salary advance request. This information should be on my tips " }\end{array}$ & $\mathrm{R} 2$ \\
\hline & & $\begin{array}{l}\text { HR Mobile } \\
\text { application }\end{array}$ & $\begin{array}{l}\text { "We scrutinize every single HR function, break it down into sub-sub functions. This } \\
\text { information is then made automated and mobile friendly for employees. The HR is on their } \\
\text { fingertips" }\end{array}$ & R16 \\
\hline & \multirow[t]{3}{*}{ Instant HR } & Instant learning & $\begin{array}{l}\text { "Every situation, every case request is a learning opportunity for me. No training } \\
\text { program can help me. It is a self-learning process and one do not have the liberty to take } \\
\text { sweet time to learn. Learn now, in the moment, today or out tomorrow." }\end{array}$ & R5 \\
\hline & & Fast response & $\begin{array}{l}\text { "Chabot's, I call it Chatter-box, do answers the folks' questions. But it does not know } \\
\text { all the answers. I step in, and give quick response to the employee. Employees don't like } \\
\text { to wait for mobile to answer their question." }\end{array}$ & $\mathrm{R} 2$ \\
\hline & & Instant outcome & $\begin{array}{l}\text { "The artificial intelligence has helped me close the positions quickly. Candidates, } \\
\text { sometimes are desperate for jobs and when they see fast turnaround on their application, } \\
\text { they accept the offer swiftly" }\end{array}$ & $\mathrm{R} 15$ \\
\hline
\end{tabular}




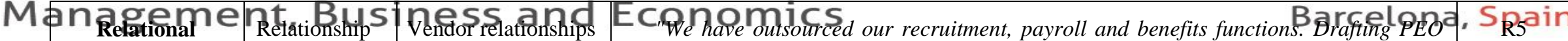

\begin{tabular}{|c|c|c|c|c|}
\hline \multirow[t]{2}{*}{$\begin{array}{l}\text { Relational } \\
\text { Virtual HR }\end{array}$} & \multirow[t]{2}{*}{$\begin{array}{l}\text { Retâtionship } \\
\text { management }\end{array}$} & Vendor relationships & \multicolumn{2}{|l|}{ - We have outsourced our recruitment, payroll and benefits functions. Brafting PEO', $\mathrm{R} 5$} \\
\hline & & Working closely & $\begin{array}{l}\text { "...and work closely with the software providers to incorporate all our services into the } \\
\text { self-service pack" }\end{array}$ & $\mathrm{R} 14$ \\
\hline & \multirow[t]{3}{*}{$\begin{array}{l}\text { Employee } \\
\text { experience }\end{array}$} & Cultural attachment & $\begin{array}{l}\text { "I spent a fair amount of time to understand the person and his cultural background. } \\
\text { My team members should not feel isolated or detached just because I am from different } \\
\text { culture" }\end{array}$ & $\mathrm{R} 8$ \\
\hline & & HR automation & $\begin{array}{l}\text { "Each of our employee is exceptional and unique. } \\
\text { Every minute of his life in the company should be a rewarding experience for him. We have } \\
\text { automated recruitment, selection, compensation, self-learning, compensation, benefits, } \\
\text { employee assistance, and performance management." }\end{array}$ & $\mathrm{R} 12$ \\
\hline & & $\begin{array}{l}\text { Employee } \\
\text { experience }\end{array}$ & $\begin{array}{l}\text { "Internal client visiting the HR department is a bad news. We take such cases very } \\
\text { seriously and take this as a missing component in out automation strategy. We want the } \\
\text { experience of the employee as smooth as whipped cream" }\end{array}$ & R16 \\
\hline & \multirow[t]{2}{*}{$\begin{array}{l}\text { Managing } \\
\text { virtual } \\
\text { diversity }\end{array}$} & Multi-linguistic & $\begin{array}{l}\text { "I ensure that the new joiners feel at home. They can't see me, but they can read and } \\
\text { hear the language. I have learnt to say Hello, How are you, How may I help you, Thank } \\
\text { you, Have a good day in } 9 \text { different languages. Sometimes, the employees correct my } \\
\text { pronunciation and I later practice the new skill on others." }\end{array}$ & $\mathrm{R} 13$ \\
\hline & & $\begin{array}{l}\text { Virtual teams } \\
\text { management }\end{array}$ & $\begin{array}{l}\text { "Steering multi-projects with the virtual teams is highly challenging as we come from } \\
\text { across various backgrounds. Be it language, family structures, sexual orientation and so } \\
\text { on" }\end{array}$ & R8 \\
\hline & \multirow[t]{2}{*}{$\begin{array}{l}\quad \text { Instant } \\
\text { social } \\
\text { networking }\end{array}$} & $\begin{array}{l}\text { Instant } \\
\text { communication }\end{array}$ & $\begin{array}{l}\text { "Supporting employees online means be vigilant to their query and action on the request } \\
\text { swiftly. I'm a prompt communicator. Even saying, Hi, I am with you and looking into your } \\
\text { request, put them to ease. The trick is, response, and response now." }\end{array}$ & $\mathrm{R} 1$ \\
\hline & & Instant relationship & $\begin{array}{l}\text { "Yes, we were people person and we still are. Just the platform has changed. How do I } \\
\text { say....It is like a blind date. If you establish relationship quickly and effectively, you acquire } \\
\text { your talent and put a ring (I mean contract)." }\end{array}$ & $\mathrm{R} 4$ \\
\hline \multirow[t]{2}{*}{$\begin{array}{l}\text { Transformational } \\
\text { Virtual HR }\end{array}$} & \multirow[t]{2}{*}{$\begin{array}{l}\text { Social } \\
\text { Branding }\end{array}$} & Personal Branding & $\begin{array}{l}\text { "I am always on phone, messaging, updating my profile, posting blogs, chatting.......You } \\
\text { name it, I am on Linkedin, facebook, twitter, instagram. Now, snapchat. My clients need to } \\
\text { know, I am working, I am making name for myself." }\end{array}$ & R6 \\
\hline & & Favorable & $\begin{array}{l}\text { "I make myself searchable, the job presentable and favorable. This is the trend, making } \\
\text { footprints on internet." }\end{array}$ & R4 \\
\hline
\end{tabular}




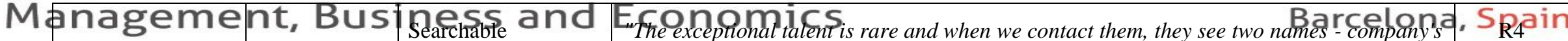
name and my name. Then what they do, ask Mr. Google. Type my name, type company's name and read, analyze, and judge us. The decision to contact me back depends on the search results."

\begin{tabular}{|c|c|c|c|c|}
\hline & & & $\begin{array}{l}\text { name and read, analyze, and judge us. The decision to contact me back depends on the } \\
\text { search results." }\end{array}$ & \\
\hline & \multirow[t]{4}{*}{$\begin{array}{r}\text { Innovative HR } \\
\text { Entrepreneur }\end{array}$} & Creative & $\begin{array}{l}\text { "The diagnostic team scan for any new request, idea, process, method, situation and deep } \\
\text { dive to either develop, create or innovate products." }\end{array}$ & $\mathrm{R} 12$ \\
\hline & & Innovative & "Innovation is the need of the hour. We need to work now to stay sustainable." & $\mathrm{R} 12$ \\
\hline & & Business Acumen & $\begin{array}{l}\text { "Reflecting back, I can safely say that we have converted strange requests from clients to a } \\
\text { new business solution. I am HR professional with business sense." }\end{array}$ & R3 \\
\hline & & Enterprising attitude & $\begin{array}{l}\text { "If my clients need a solution and I don't have an answer, I hire another consultant. It is a } \\
\text { win-win situation. Keeping clients satisfied with our HR services means repetitive } \\
\text { business." }\end{array}$ & R3 \\
\hline \multirow[t]{8}{*}{$\begin{array}{l}\text { Technological } \\
\text { Virtual HR }\end{array}$} & \multirow[t]{4}{*}{$\begin{array}{c}\text { Technological } \\
\text { know-how }\end{array}$} & Coding & $\begin{array}{l}\text { "Coding runs in my blood. During our product development meetings, I can understand the } \\
\text { language of the programmers. The knowledge of coding is crucial for HR people. } \\
\text { Otherwise, they will not get the product or software they want for their job." }\end{array}$ & $\mathrm{R} 12$ \\
\hline & & $\begin{array}{l}\text { Knowledge of SaaS } \\
\text { (software as a } \\
\text { service) }\end{array}$ & $\begin{array}{l}\text { "People think that HRIS equals portal. We run the projects with wide range of HR } \\
\text { Technologies, whether it be SaaS suites or any other delivery model" }\end{array}$ & $\mathrm{R} 7$ \\
\hline & & $\begin{array}{l}\text { Knowledge of the } \\
\text { technological } \\
\text { updates }\end{array}$ & $\begin{array}{l}\text { "A year back, our focus was on resume screening technology. It is a default feature. We } \\
\text { are looking more into intelligent automation and Chabot compatibility" }\end{array}$ & $\mathrm{R} 11$ \\
\hline & & $\begin{array}{l}\text { Knowledge of SaaS } \\
\text { (software as a } \\
\text { service) }\end{array}$ & $\begin{array}{l}\text { "People think that HRIS equals portal. We run the projects with wide range of HR } \\
\text { Technologies, whether it be SaaS suites or any other delivery model" }\end{array}$ & $\mathrm{R} 7$ \\
\hline & \multirow{4}{*}{$\begin{array}{l}\text { Technological } \\
\text { Business } \\
\text { Acumen }\end{array}$} & $\begin{array}{l}\text { Technical } \\
\text { Consultancy }\end{array}$ & $\begin{array}{l}\text { "We have developed a team of HR Technographers to consult our HR telecommuters with } \\
\text { respect to the technology, shared services and offshoring" }\end{array}$ & $\mathrm{R} 14$ \\
\hline & & $\begin{array}{l}\text { Technology } \\
\text { selection }\end{array}$ & $\begin{array}{l}\text { "We are in the process of shortlisting the recruitment software. The offerings, the } \\
\text { facilitations, and the bundle packages have made the decision difficult." }\end{array}$ & $\mathrm{R} 11$ \\
\hline & & Technical etiquettes & $\begin{array}{l}\text { "Online HR consultants like me must be competent in putting email, internet, intranet, } \\
\text { teleconferencing systems, and collaborative softwares to professional use." }\end{array}$ & R 3 \\
\hline & & $\begin{array}{l}\text { Technological } \\
\text { advancement }\end{array}$ & $\begin{array}{l}\text { "....and suggest HRIS department to improve the payroll module. The data should be error } \\
\text { free. The machine should not generate faulty reports or consume corrupted data" }\end{array}$ & R9 \\
\hline
\end{tabular}




\section{Findings}

The latent-inductive thematic analysis produced 36 competencies, clustered into 14 groups, and allocated to 4 competency domains. Spencer and Spencer (1993) defined a competency cluster as "a group of distinguishing competencies" and Brockbank and Ulrich (2003) theorized that the competency factors are the smallest unit of competencies. Thirty-six (36) competencies specific to virtual HR professionals were captured. These competencies were data interpretation, data analysis, drafting agreements, intellectual property, confidentiality agreements, time-zones management, knowledge of HR mobile application, HR Mobile application, instant learning, fast response, instant outcome, vendor relationships, working closely, cultural attachment, HR automation, employee experience, multi-linguistic, virtual teams management, instant communication, instant relationship, personal branding, favorable image, searchable, creative, innovative, business acumen, enterprising attitude, coding, knowledge of SaaS, knowledge of the technological updates, technical consultancy, technology selection, technical etiquettes, and technological advancement.

Due to similar attributes of competencies, MOSAIC approach was used to cluster the competency factors which yielded fourteen (14) competency clusters - Data science, Agreement/Contract management, managing time zones, mobile HR, instant HR, relationship management, employee experience management, managing virtual diversity, instant social networking, social branding, innovative HR entrepreneur, technological know-how, and technological business acumen. The MOSAIC approach offered an Integrative approach to frame the virtual HR competencies, especially in the context of the automated HR in AI age.

\section{Conclusion, Research Implementation and Limitations}

Combining the results from the meta-analysis of the HR Competency models, thematic analysis of semi-structured interviews, and building on the work of Bondarouk et al. (2017) and Ruël et al. (2007), a Virtual HR Competency Model (Figure 3) has emerged. This framework rests on four pillars of virtual HR - Operational, Relational, Transformational, and Technological. It differentiates the unique competencies required in the virtual $\mathrm{HR}$ professionals to work in an automated environment.

This research recommends the competencies that will be required in HR professionals to work in the Age of Artificial Intelligence. As the study has projected the competencies for 2030, the target workforce will be Generation Z (born between 1995-2010) and Millennials (born between 1981-1995). The True Digital Natives will constitute the workforce in 2030 characterized by telecommuters with global citizenship and instant acquisition and application of new learning. The new competencies provided through this study will help education ministries, curriculum developers, and educators to develop the futuristic competencies in the HR graduates.

In conclusion, the answers to the research questions regarding existing HR competencies for virtual HR professionals and the competencies affected by the Artificial Intelligence gave birth to the Virtual HR Competency model that suggests the competencies required in virtual HR professionals for the future HR jobs. The report on the Next Era of Human proposed the development of a new set of individual skills and traits (Institute for the future, 2017) and this model will provide a light towards preparing the new workforce. 


\section{International Conference on Applied Research in Management, Business and Economics}

Figure 3: Virtual HR Competency Model

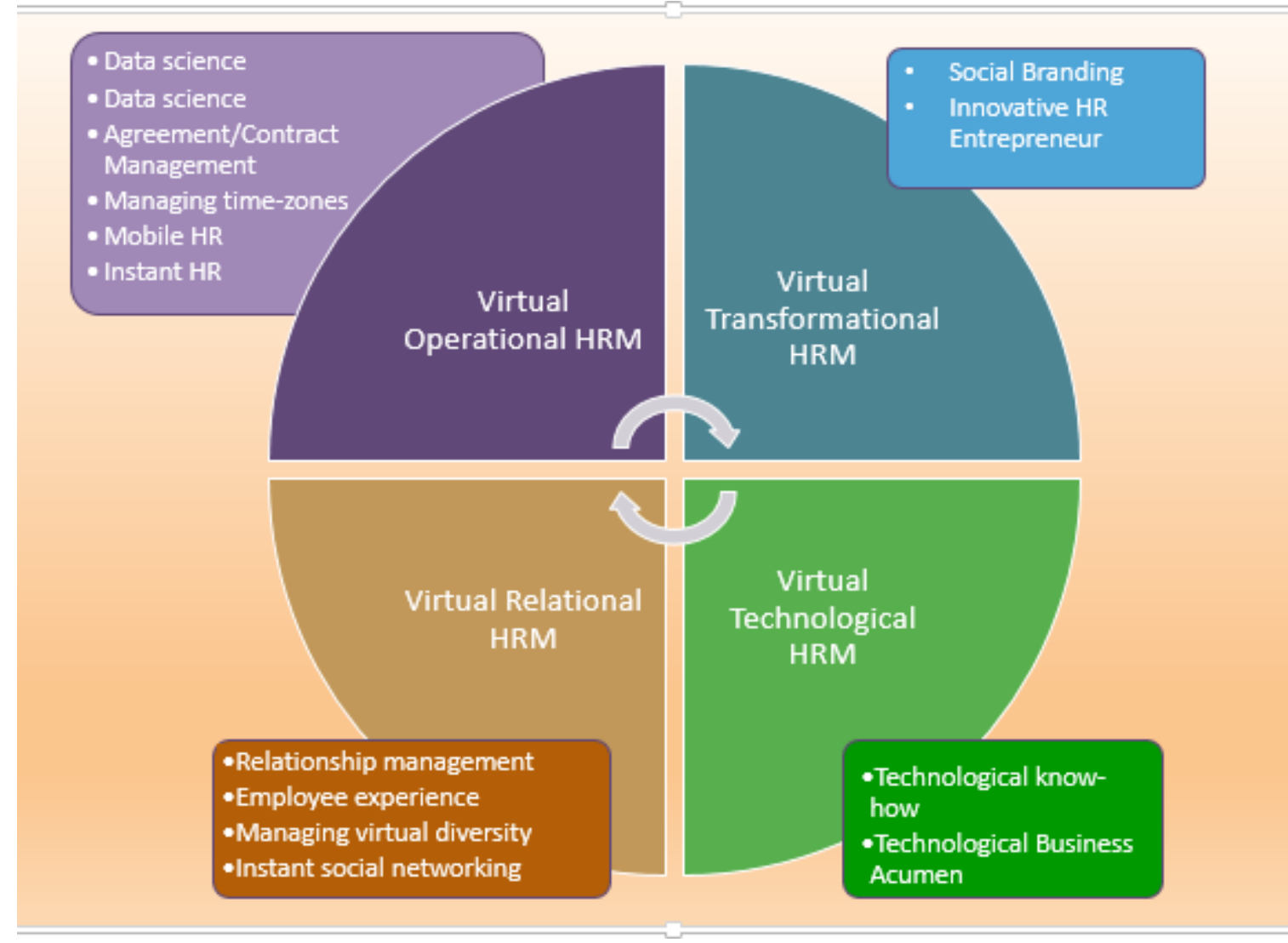

The study will support HR professionals to acquire, develop, and retain the professionals by benchmarking the virtual HR competencies. The future jobs in HR will not be limited to VP of HR - Data, AI \& Offering Strategy; HR Analytics specialist; Director of People Systems; Workforce Intelligence Officer; Chief HR Technology Officer; HR Chatbot Operator; Head of HR Digital transformation; and AI Employee. The results of this study will assist HR professionals to complete job-analysis and competency mapping. The organization developers, policymakers, researchers, organizations, and consultants also will reap the benefits of this study.

Though based on the extensive review of the literature and insights from the virtual HR professionals, this empirical study remains in its pilot mode. The competency domains, clusters, and factors are to be quantitatively tested. In future, the researcher aims to test the Virtual Competency Model from all the three perspectives of competencies - competency for the job, competency for the organization, and competency of an individual. Also, the researcher plans to apply mixed-methodology and triangulate the data to affirm the findings of both the qualitative research and the quantitative research. Job Analysis of future HR jobs is also planned to pair the virtual competencies, rank the competencies, and create a competency profile for jobs in the age of Artificial Intelligence. 


\section{International Conference on Applied Research in Management, Business and Economics}

\section{References}

Bondarouk, T., Marsman, E., \& Rekers, M. (2014). HRM, technology and innovation: New HRM competences for old business challenges? In Human Resource Management, Social Innovation and Technology (Vol. 14, pp. 179-215). Emerald Group Publishing Limited. https://doi.org/10.1108/S1877-636120140000014016

Bondarouk, T., Parry, E., \& Furtmueller, E. (2017). Electronic HRM: four decades of research on adoption and consequences. The International Journal of Human Resource Management, 28(1), 98-131. https://doi.org/10.1080/09585192.2016.1245672

Boyatzis, R. E. (2008). Competencies in the 21st century. Journal of Management Development, 27(1), 5-12. https://doi.org/10.1108/02621710810840730

Boyatzis, R. E. (2011). Managerial and leadership competencies: A behavioral approach to emotional, social and cognitive intelligence. Vision: The Journal of Business Perspective, 15(2), 91-100. https://doi.org/10.1177/097226291101500202

Braun, V., \& Clarke, V. (2006). Using thematic analysis in psychology. Qualitative Research in Psychology, 3(2), 77-101. http://dx.doi.org.ezproxy.hct.ac.ae/10.1191/1478088706qp063oa

Byrd, M. Y. (2017). The history of human resource development. New Horizons in Adult Education and Human Resource Development, 29(2), 66-68. https://doi.org/10.1002/nha3.20182

Charlier, R., \& Kloppenburg, S. (2017). Artificial intelligence in HR: a No-brainer (pp. 1-8). PwC People \& Organisation. Retrieved from https://www.pwc.at/de/publikationen/.../artificialintelligence-in-hr-a-no-brainer.pdf

Creswell, J. W. (2009). Research design: qualitative, quantitative, and mixed methods approaches (3rd ed.). Los Angeles: Sage.

Gardner, S. D., Lepak, D. P., \& Bartol, K. M. (2003). Virtual HR: The impact of information technology on the human resource professional. Journal of Vocational Behavior, 63(2), 159179. https://doi.org/10.1016/S0001-8791(03)00039-3

Gosney, M. W., \& Hughes, C. (2016). The history of human resource development: Understanding the unexplored philosophies, theories, and methodologies. https://doi.org/10.1057/9781137526984

Harvey Nash. (2018). Harvey nash HR survey (pp. 1-16). Retrieved from https://www.harveynash.com/hrsurvey/

Hébert, R., Durand, P. J., Dubuc, N., \& Tourigny, A. (2003). PRISMA: a new model of integrated service delivery for the frail older people in Canada. International Journal of Integrated Care, 3. Retrieved from https://www.ncbi.nlm.nih.gov/pmc/articles/PMC1483944/

HQ Asia. (2017). How AI will influence core competencies of the future. Retrieved January 23, 2019, from https://hcli.org/articles/how-ai-will-influence-core-competencies-future

Ilham, S. (2012). Human resource competency models: Changing evolutionary trends. Interdisciplinary Journal of Research in Business, 1(11), 11-25.

Institute for the future. (2017). The Next Era of Human|Machine Partnerships (pp. 1-23). California, United States. Retrieved from http://www.iftf.org/humanmachinepartnerships/

Kakabadse, N., \& Kakabadse, A. (2000). Critical review - Outsourcing: a paradigm shift. Journal of Management Development, 19(8), 670-728. https://doi.org/10.1108/02621710010377508

Lawler, E. E., Fitz-enz, J., Madden, J., Ulrich, D., \& Books24x7, I. (2004). Human resources business process outsourcing: Transforming how HR gets its work done (1. Aufl.;1st;). US: JosseyBass.

Lejeune, T. (2013). HR embracing mobile technology soon?: Towers Watson survey suggests HR use of mobile apps is rising slowly but steadily. Employee Benefit News (Online); New York.

Retrieved from https://search.proquest.com/docview/1912105327/abstract/24E934CB12364C73PQ/1

Lepak, D. P., \& Snell, S. A. (1998). Virtual HR: Strategic human resource management in the 21st century. Human Resource Management Review, 8(3), 215-234.

https://doi.org/10.1016/S1053-4822(98)90003-1 


\section{International Conference on Applied Research in Management, Business and Economics}

Maguire, M., \& Delahunt, B. (2017). Doing a thematic analysis: A practical, step-by-step guide for learning and teaching scholars. AISHE-J: The All Ireland Journal of Teaching and Learning in Higher Education, 9(3). Retrieved from http://ojs.aishe.org/index.php/aishe-j/article/view/335

Manuti, A., \& de Palma, P. D. (2017). Digital HR: A critical management approach to the digitilization of organizations. Cham: Palgrave Macmillan US.

Manyika, J., Lund, S., Chui, M., Bughin, J., Woetzel, J., Batra, P., ... Sanghvi, S. (2017). Jobs lost, jobs gained: What the future of work will mean for jobs, skills, and wages. McKinsey Global Institute. Retrieved from https://www.mckinsey.com/featured-insights/future-of-work/jobslost-jobs-gained-what-the-future-of-work-will-mean-for-jobs-skills-and-wages

Marsman, E., Bondarouk, T., \& Rekers, M. (2014). HRM, Technology and Innovation: New HRM Competences for Old Business Challenges? In Human Resource Management, Social Innovation and Technology (Vol. 14, pp. 179-215). Emerald Group Publishing Limited. https://doi.org/10.1108/S1877-636120140000014016

McClelland, D. C. (1973). Testing for competence rather than for "intelligence." The American Psychologist, 28(1), 1-14. https://doi.org/10.1037/h0034092

Melcer, R. (2001). Virtual HR department spells out benefits online. Business Courier; Cincinnati, $17(47), 3$.

Min, J.-A. (2017). Best of TLNT 2017: The HR skills you'll need in the Age of AI. Retrieved January 23, 2019, from https://www.tlnt.com/the-hr-skills-youll-need-in-the-age-of-ai/

Nunn, D. J. (2018). How AI is transforming HR departments. Retrieved January 23, 2019, from https://www.forbes.com/sites/forbestechcouncil/2018/05/09/how-ai-is-transforming-hrdepartments/

Patel, S. (2015, July 15). The research paradigm - methodology, epistemology and ontology explained in simple language. Retrieved June 17, 2017, from http://salmapatel.co.uk/academia/the-research-paradigm-methodology-epistemology-andontology-explained-in-simple-language

PwC. (2018). Workforce of the future - The competing forces shaping 2030 (pp. 1-42). Retrieved from https://www.pwc.com/gx/en/services/people-organisation/publications/workforce-of-thefuture.html

Ruël, H. J. M., Bondarouk, T. V., \& Van der Velde, M. (2007). The contribution of e-HRM to HRM effectiveness: Results from a quantitative study in a Dutch Ministry. Employee Relations; Bradford, 29(3), 280-291. http://dx.doi.org.ezproxy.hct.ac.ae/10.1108/01425450710741757

Selmer, J., \& Chiu, R. (2004). Required human resources competencies in the future: a framework for developing HR executives in Hong Kong. Journal of World Business, 39(4), 324-336. https://doi.org/10.1016/j.jwb.2004.08.001

Shook, E., \& Knickrehm, M. (2017). Harnessing revolution: Creating the future workplace. Accenture strategy. Retrieved from https://www.accenture.com/t20170210T012359_w__/usen/_acnmedia/PDF-40/Accenture-Strategy-Harnessing-Revolution-POV.pdf

SHRM. (2008). A history of human resources: SHRM's 60-year journey. Alexandria, VA: Society for Human Resource Management.

Snell, S., Stueber, D., \& Lepak, D. (2001). Virtual HR Departments: Getting Out of the Middle. CAHRS Working Paper Series, 1-31.

Stevens, M. R., Lyles, W., \& Berke, P. R. (2014). Measuring and reporting intercoder reliability in plan quality evaluation research. Journal of Planning Education and Research, 34(1), 77-93. https://doi.org/10.1177/0739456X13513614

Svetlik, I., \& Stavrou-Costea, E. (2007). HRM in a Knowledge Based Economy. International Journal of Manpower, $28(3 \& 4)$.

Swanson, R. A., \& Holton, E. F. (2009). Foundations of human resource development (2nd ed.). San Francisco, CA: Berrett-Koehler.

Ulrich, D. (2015). HR Competency Model 2016. Presented at the HR Competency Conference. Retrieved from http://www.apg.pt/downloads/file954_pt.pdf 


\section{International Conference on Applied Research in Management, Business and Economics}

Venegas, B. C., \& Thill, K. (2015). Towards a New Competency Model for Hrm. the Art of

Competency Modelling - a New Approach for Hrm. International Journal of Arts \& Sciences; Cumberland, 8(5), 597-621.

Yeung, A. K. (1996). Competencies for HR Professionals: An Interview with Richard E. Boyatzis. Human Resource Management (1986-1998); New York, 35(1), 119.

\section{Appendix}

Appendix 1: HR Competency Model (1988-2016)

\begin{tabular}{|c|c|c|c|c|c|c|c|}
\hline & $\begin{array}{c}\text { Round } 1 \\
1987 \\
\end{array}$ & $\begin{array}{c}\text { Round } 2 \\
1992 \\
\end{array}$ & $\begin{array}{c}\text { Round } 3 \\
1997 \\
\end{array}$ & $\begin{array}{c}\text { Round } 4 \\
2002 \\
\end{array}$ & $\begin{array}{c}\text { Round } 5 \\
2007 \\
\end{array}$ & $\begin{array}{c}\text { Round } 6 \\
2012 \\
\end{array}$ & $\begin{array}{c}\text { Round } 7 \\
2016 \\
\end{array}$ \\
\hline \multirow{2}{*}{ Business } & \multirow{2}{*}{$\begin{array}{l}\text { Business } \\
\text { Knowledge }\end{array}$} & \multirow{2}{*}{$\begin{array}{l}\text { Business } \\
\text { Knowledge }\end{array}$} & \multirow{2}{*}{$\begin{array}{l}\text { Business } \\
\text { Knowledge }\end{array}$} & $\begin{array}{l}\text { Business } \\
\text { Knowledge }\end{array}$ & Business Ally & \multirow{2}{*}{$\begin{array}{l}\text { Strategic } \\
\text { Positioner }\end{array}$} & \multirow{2}{*}{ Strategic Positioner } \\
\hline & & & & $\begin{array}{c}\text { Strategic } \\
\text { Contribution }\end{array}$ & $\begin{array}{l}\text { Strategic } \\
\text { Architect }\end{array}$ & & \\
\hline \multirow{6}{*}{$\begin{array}{c}\text { Human } \\
\text { Resources } \\
\text { (HR) }\end{array}$} & \multirow{6}{*}{$\begin{array}{c}\text { HR } \\
\text { Delivery }\end{array}$} & \multirow{6}{*}{ HR Delivery } & \multirow{6}{*}{$\begin{array}{c}\text { HR } \\
\text { Delivery }\end{array}$} & \multirow{3}{*}{ HR Delivery } & \multirow{3}{*}{$\begin{array}{c}\text { Talent } \\
\text { Manager \& } \\
\text { Organization } \\
\text { Designer }\end{array}$} & \multirow{3}{*}{$\begin{array}{c}\text { HR } \\
\text { Innovator \& } \\
\text { Integrator }\end{array}$} & $\begin{array}{l}\text { Human Capital } \\
\text { Curator }\end{array}$ \\
\hline & & & & & & & Total Rewards Steward \\
\hline & & & & & & & $\begin{array}{c}\text { Analytics Designer and } \\
\text { Interpreter }\end{array}$ \\
\hline & & & & \multirow{3}{*}{$\begin{array}{c}\text { HR } \\
\text { Technology }\end{array}$} & \multirow{3}{*}{$\begin{array}{l}\text { Operational } \\
\text { Executor }\end{array}$} & \multirow{3}{*}{$\begin{array}{l}\text { Technology } \\
\text { Proponent }\end{array}$} & Compliance Manager \\
\hline & & & & & & & $\begin{array}{l}\text { Technology \& Media } \\
\text { Integrator }\end{array}$ \\
\hline & & & & & & & Paradox Navigator \\
\hline Change & Change & Change & Change & \multirow{2}{*}{$\begin{array}{c}\text { Strategic } \\
\text { Contribution }\end{array}$} & \multirow{2}{*}{$\begin{array}{c}\text { Culture And } \\
\text { Change } \\
\text { Steward }\end{array}$} & $\begin{array}{c}\text { Change } \\
\text { Champion }\end{array}$ & \multirow{2}{*}{$\begin{array}{l}\text { Culture and Change } \\
\text { Champion }\end{array}$} \\
\hline Culture & & & Culture & & & $\begin{array}{l}\text { Capability } \\
\text { Builder }\end{array}$ & \\
\hline Personal & & $\begin{array}{l}\text { Personal } \\
\text { Credibility }\end{array}$ & $\begin{array}{l}\text { Personal } \\
\text { Credibility }\end{array}$ & $\begin{array}{l}\text { Personal } \\
\text { Credibility }\end{array}$ & $\begin{array}{l}\text { Credible } \\
\text { Activist }\end{array}$ & $\begin{array}{l}\text { Credible } \\
\text { Activist }\end{array}$ & Credible Activist \\
\hline
\end{tabular}

(Source: Ulrich, 2015, P.73)

Appendix 2: Competencies mentioned in HR Competency Models

\begin{tabular}{|l|c|c|c|l|l|l|l|}
\hline HR Competencies & $\begin{array}{c}\text { ASTD } \\
\mathbf{( 1 9 8 8 )}\end{array}$ & $\begin{array}{c}\text { Kearns } \\
\mathbf{( 2 0 0 1 )}\end{array}$ & $\begin{array}{l}\text { Selmer \& } \\
\text { Randy } \\
\mathbf{( 2 0 0 4 )}\end{array}$ & $\begin{array}{l}\text { Chen } \\
\mathbf{( 2 0 0 5 )}\end{array}$ & $\begin{array}{l}\text { SHR } \\
\text { M } \\
\mathbf{( 2 0 1 2})\end{array}$ & $\begin{array}{l}\text { CIPD } \\
\mathbf{( 2 0 1 3 )}\end{array}$ & $\begin{array}{l}\text { Ulrich } \\
\mathbf{( 2 0 1 6}\end{array}$ \\
\hline Accountability & & $\checkmark$ & & & & & \\
\hline Analytical Designer \& Interpreter & & & & $\checkmark$ & & & $\checkmark$ \\
\hline Analytical thinking & & & & $\checkmark$ & & & \\
\hline Business Acumen \& Ally & $\checkmark$ & $\checkmark$ & $\checkmark$ & $\checkmark$ & $\checkmark$ & $\checkmark$ & \\
\hline Change management & & & $\checkmark$ & & & & $\checkmark$ \\
\hline Communication & $\checkmark$ & $\checkmark$ & & $\checkmark$ & & & \\
\hline Compliance Management & & & & & & & $\checkmark$ \\
\hline Consultation and Advisory skills & & & & & $\checkmark$ & & \\
\hline Continuous learning & & $\checkmark$ & & & & $\checkmark$ & \\
\hline
\end{tabular}


International Conference on Applied Research in

Management, Business and Economics

\begin{tabular}{|c|c|c|c|c|c|c|c|}
\hline Courage to Challenge & & & & & & $\checkmark$ & \\
\hline Creativity \& innovation & $\checkmark$ & $\checkmark$ & $\checkmark$ & & & & \\
\hline Credible & & & & & & $\checkmark$ & $\checkmark$ \\
\hline Critical evaluation & & & & & $\checkmark$ & & \\
\hline Cultural management & & & $\checkmark$ & & & & $\checkmark$ \\
\hline Curious & & & & & & $\checkmark$ & \\
\hline Decision Making & $\checkmark$ & $\checkmark$ & & & & & \\
\hline Diversity Management & & $\checkmark$ & $\checkmark$ & & $\checkmark$ & & \\
\hline Employee engagement & & & & & & $\checkmark$ & \\
\hline Employee involvement & & & $\checkmark$ & & & & \\
\hline Empowerment & & $\checkmark$ & $\checkmark$ & & & & \\
\hline Ethical practice & & & & & $\checkmark$ & & \\
\hline HRM concept \& functional knowledge & $\checkmark$ & & $\checkmark$ & & $\checkmark$ & $\checkmark$ & \\
\hline Human Capital Curator & & & & & & & $\checkmark$ \\
\hline Influencer & & & & & & $\checkmark$ & \\
\hline Integrity & & $\checkmark$ & & & & & \\
\hline International Management & & & $\checkmark$ & & & & \\
\hline Interpersonal relationship & $\checkmark$ & & $\checkmark$ & $\checkmark$ & $\checkmark$ & $\checkmark$ & \\
\hline Knowledge Management & & & & $\checkmark$ & & & \\
\hline Leadership & $\checkmark$ & $\checkmark$ & $\checkmark$ & $\checkmark$ & $\checkmark$ & $\checkmark$ & \\
\hline Market knowledge & & & $\checkmark$ & & & & \\
\hline Media Integrator & & & & & & & $\checkmark$ \\
\hline Negotiation skills & $\checkmark$ & & & & & & \\
\hline Operational executor & & & & & & & $\checkmark$ \\
\hline Organization Designer/Developer & & & $\checkmark$ & & & $\checkmark$ & \\
\hline Professionalism & & $\checkmark$ & & & & & \\
\hline Project Management & & & $\checkmark$ & $\checkmark$ & $\checkmark$ & & \\
\hline Rewards Management & & & & & & $\checkmark$ & $\checkmark$ \\
\hline Role Model & & & & & & $\checkmark$ & \\
\hline Strategy architect/ positioner & & $\checkmark$ & $\checkmark$ & & & $\checkmark$ & $\checkmark$ \\
\hline System thinking & & & & $\checkmark$ & & & \\
\hline Talent management & & $\checkmark$ & $\checkmark$ & & & $\checkmark$ & \\
\hline Team work \& team development & $\checkmark$ & $\checkmark$ & $\checkmark$ & & & $\checkmark$ & \\
\hline Technical relationship & $\checkmark$ & & & $\checkmark$ & & & \\
\hline Technological Acumen & $\checkmark$ & $\checkmark$ & & $\checkmark$ & & & $\checkmark$ \\
\hline Trust & & $\checkmark$ & & & & & \\
\hline Total Competencies $=45$ & 11 & 16 & 17 & 11 & 9 & 16 & 10 \\
\hline
\end{tabular}


Appendix 3: Concurrence of virtual HR practitioner with the theoretical HR competencies

\begin{tabular}{|c|c|c|}
\hline Competency Domain & $\begin{array}{l}\text { HR Competencies from literature } \\
\text { (theoretical HR) }\end{array}$ & $\begin{array}{l}\text { Frequency in } \\
\text { quotations from } \\
\text { interviews } \\
\text { (practical HR) }\end{array}$ \\
\hline \multirow[t]{6}{*}{ Virtual Operational HRM } & HR Measurement & 19 \\
\hline & Organizational capability & 4 \\
\hline & Online knowledge management & 23 \\
\hline & Globalized Legal Compliance & 15 \\
\hline & Self-learning and development & 8 \\
\hline & Knowledge of HR technology & 29 \\
\hline \multirow[t]{6}{*}{ Virtual Relational HRM } & Flexibility and adaptability & 13 \\
\hline & Conversation buddy & 5 \\
\hline & Virtual identity & 4 \\
\hline & Wide orientation & 17 \\
\hline & Self-reflection & 2 \\
\hline & Independence & 11 \\
\hline \multirow{5}{*}{$\begin{array}{l}\text { Virtual Transformational } \\
\text { HRM }\end{array}$} & Organization sensitivity & 3 \\
\hline & Cultural management & 21 \\
\hline & Change management & 33 \\
\hline & Innovative & 18 \\
\hline & Feasibility analysis & 2 \\
\hline
\end{tabular}

